Vol. 7, No. 1, 2020

https://doi.org/10.23939/eem2020.01.048

UDC 005.4

JEL Classification Code: M10

O. Melnyk
Lviv Polytechnic National University, Doctor of Economics, Professor, Head of the department
e-mail: olia_melnyk@ukr.net
ORCID: 0000-0001-8819-1910

M. Zlotnik

Lviv Polytechnic National University, postgraduate student e-mail: martazlotnik@gmail.com ORCID: 0000-0002-4313-6771

\title{
THE ESSENCE AND BASIC MODELS OF STRATEGIC ENTERPRISE MANAGEMENT
}

\begin{abstract}
The scientific approaches of Ukrainian and foreign scientists to the interpretation of the concept of strategic enterprise management and compares their characteristics are systematized in this article; different stages of evolution of strategic management systems in the context of functioning of scientific schools are analyzed, their basic principles are presented and their key representatives are singled out; the comparative analysis of approaches of different scientific schools is carried out, advantages and disadvantages of their views on strategic management and strategy formation are determined. For further structuring of knowledge in the field of strategic management, the essence of the concept of strategy was determined according to the interpretation of different scientists and the organization strategies were classified by key characteristics and levels of implementation; their key characteristics have been identified. Particular attention is paid to basic models of strategic enterprise management, taking into account their features, advantages and disadvantages; the structure and algorithms of strategic management based on the analyzed models are graphically demonstrated. According to the results of the research, conclusions were drawn regarding the theoretical bases of understanding the essence of strategic management of enterprises and differences in their interpretation in the works of different authors, characteristics of basic models of strategic management are generalized, the importance of strategic management to ensure the
\end{abstract}

effective operation of the organization is emphasized; the features of strategic management in the conditions of the modern changing environment are characterized and the expediency of basic models of strategic management for modern enterprises is determined, the proposals for the further development and deepening of the investigated topic are developed.

Key words: strategic management, models of strategic enterprise management, mission, goals, envinronment analisys.

\section{Introduction}

Creating an effective enterprise strategic management system can provide competitive advantage over the long term and establish a firm strategic position for the organization that can ensure its future viability in a changing environment.

At the present stage of development, strategic management should become the basis and at the same time an instrument of effective longterm development of an enterprise of any industry, in order to solve long-term economic problems and achieve socio-economic efficiency.

In order to systematize and compare the main approaches to strategic management, it is advisable to consider the essence, basic theories and models of strategic enterprise management. 


\section{Problem formulation}

Systematization and comparative characterization of existing scientific approaches to the interpretation of the essence of strategic enterprise management, defining its key models and the analysis of varieties of strategies at different stages of the evolution of management systems as well as identification of their substantive characteristics.

\section{Analysis of the latest publications}

Based on the analysis of literary sources, it was found that strategic management is considered by authors in three aspects: as a type of activity, as a process and as a system. Detailed descriptions of different interpretations of the concept of "strategic enterprise management", from the point of view of Ukrainian and foreign authors, are given in Table 1.

\section{Approaches of Ukrainian and foreign authors to the interpretation of the concept of "strategic enterprise management"}

\begin{tabular}{|c|c|c|}
\hline Author & Aspect & Meaning \\
\hline I. Ansoff $[1,2]$ & \multirow{3}{*}{$\begin{array}{l}\text { As a type of } \\
\text { activity }\end{array}$} & $\begin{array}{l}\text { Activities related to defining the goals and objectives of the organization and } \\
\text { ensuring the relationship between the organization and the external } \\
\text { environment, which corresponds to its internal capabilities and allows it to } \\
\text { remain receptive to external requirements }\end{array}$ \\
\hline L. Romaniuk [3] & & $\begin{array}{l}\text { A set of strategic management decisions that determine the long-term development of } \\
\text { the organization, but also specific actions that ensure the rapid response of the } \\
\text { organization to changes in the environment, which may cause the need for strategic } \\
\text { maneuver, review goals and choose a new direction of development }\end{array}$ \\
\hline $\begin{array}{l}\text { M. Martynenko } \\
\text { [4] }\end{array}$ & & $\begin{array}{l}\text { A set of strategic management decisions aimed at the long-term development of } \\
\text { the company, as well as specific actions that ensure the rapid response of the } \\
\text { company to changing conditions in the external environment }\end{array}$ \\
\hline $\begin{array}{l}\text { O. Vikhanskyi } \\
\text { [5] }\end{array}$ & \multirow{8}{*}{$\begin{array}{l}\text { As a } \\
\text { process }\end{array}$} & $\begin{array}{l}\text { Dynamic process of analysis, selection of strategies, planning, provision and } \\
\text { implementation of the plans developed by the organization, which consists in a } \\
\text { repeated cycle of implementation of its main tasks }\end{array}$ \\
\hline M. Kadyrov [6] & & $\begin{array}{l}\text { The process of making and implementing strategic decisions, the central part of } \\
\text { which is strategic planning, is based on a comparison of the resource potential } \\
\text { of an organization with the capabilities and threats of the external environment } \\
\text { in which it operates }\end{array}$ \\
\hline $\begin{array}{l}\text { A. Thompson, } \\
\text { A. J. Strickland } \\
\text { [7] }\end{array}$ & & $\begin{array}{l}\text { The process by which managers set long-term directions for the development of } \\
\text { an organization, its specific goals, determine strategies for their achievement, } \\
\text { taking into account all possible internal and external circumstances, and } \\
\text { implement the selected action plans }\end{array}$ \\
\hline $\begin{array}{l}\text { Z. Shershnova } \\
{[8]}\end{array}$ & & $\begin{array}{l}\text { A multi-faceted, formal-behavioral management process that helps formulate } \\
\text { and execute effective strategies that help to balance the relationship between the } \\
\text { organization and the environment, as well as achieve the goals set }\end{array}$ \\
\hline K. Hatten [9] & & $\begin{array}{l}\text { The process of forming the goals of the organization and the management } \\
\text { process to achieve them }\end{array}$ \\
\hline J. Higgins [10] & & $\begin{array}{l}\text { Management process to accomplish an organization's mission by managing the } \\
\text { interaction of the organization with its environment }\end{array}$ \\
\hline $\begin{array}{l}\text { D. Shendel, } \\
\text { K. Patton [11] }\end{array}$ & & $\begin{array}{l}\text { The process of identifying and linking an organization with its environment, } \\
\text { which is formed in the process of achieving the chosen goals, ways to achieve } \\
\text { the desired state of relations with the environment through such a distribution } \\
\text { of resources that allows the organization and its departments to operate } \\
\text { effectively and efficiently }\end{array}$ \\
\hline $\begin{array}{l}\text { J. Smith, } \\
\text { D. Arnold, } \\
\text { B. Bizzell [12] }\end{array}$ & & $\begin{array}{l}\text { The process of environmental assessment, formulation of organizational goals, } \\
\text { decision-making, their implementation and control, rigged to achieve the goals } \\
\text { and future external environment of the organization }\end{array}$ \\
\hline G. Kleiner [13] & \multirow[t]{2}{*}{ As a system } & $\begin{array}{l}\text { An enterprise management system based on strategic planning and mechanisms } \\
\text { for aligning current decisions with strategic ones }\end{array}$ \\
\hline S. Popov [14] & & Highly professional management activity with its own structural specialization \\
\hline
\end{tabular}




\section{O. Melnyk, M. Zlotnik}

Summarizing, it can be argued that the common feature of all the above definitions is the connection of strategic management with the analysis of various aspects of the organization's activities, the relationship with the external environment, the formation of goals of the enterprise, and management decisions to implement them.

\section{The essence of strategies and their classification}

The result of strategic enterprise management is strategy. It is the main link between the internal and external environment of the organization. American scientist I. Ansoff noted that "... companies, in the absence of a planned and managed strategy, are doomed to extinction ... Strategic behavior is at least governed by companies that survive".

In order to systematize knowledge about strategic enterprise management, it is advisable to analyze different scientific approaches to explaining the term "strategy" and its main varieties.

Scientists such as I Ansoff [1, 2], A. Thompson, A. J. Strickland [7], M. Porter [15], and
O. Vikhanskyi [5] have developed their own approaches to defining the concept of "strategy". Important contributions to the development of the theory of strategic management have also been made by Ukrainian authors such as G. Kindratska [16], Z. Shershneva [8], and others.

In scientific theory there is no universal interpretation of the content of the strategy and its structure, which emphasizes the complexity, versatility and ambiguity of understanding of this concept. The overall definition of the category "enterprise strategy" of different authors has common characteristics, but there are differences in the interpretation of its individual components.

The strategy is interpreted as a specific plan of activity of the company, related to the position of the company in the market, both today and in the future. The term "strategy" has been used in management science and practice since the 1950s. Business strategy is considered one of the main concepts in strategic management. Various scientists have proposed many definitions of the term "strategy" (Table 2).

Table 2

The authors' approaches to interpreting the term "strategy"

\begin{tabular}{|l|l|}
\hline \multicolumn{1}{|c|}{ Author } & \multicolumn{1}{c|}{ Definition. } \\
\hline I Ansoff [1,2] & A strategy is a list of decision-making rules that an organization guides in its operations \\
\hline $\begin{array}{l}\text { A. Thompson, } \\
\text { A. J. Strickland [7] }\end{array}$ & $\begin{array}{l}\text { A strategy is a plan of management of the company, aimed at strengthening its position, } \\
\text { customer satisfaction and achievement of the set tasks }\end{array}$ \\
\hline $\begin{array}{l}\text { Ye. Velesko, } \\
\text { O. Bykov, } \\
\text { Z. Drazhek [17] }\end{array}$ & A strategy is the art of leadership, the overall plan of doing things \\
\hline S. Oster [18] & A strategy is a commitment to act in one way, not another \\
\hline B. Henderson [19] & $\begin{array}{l}\text { A strategy is a careful study of an action plan that develops and multiplies competitive } \\
\text { advantage in business }\end{array}$ \\
\hline
\end{tabular}

It can be summarized that the strategy is a long-term, well-defined direction of development of the enterprise, aimed at consolidating its positions, customer satisfaction and achievement of the set goals. It is designed to determine which direction the business will develop and make decisions when choosing how to proceed.

In management theory, an important concept is the concept of the basic strategy of the enterprise. The core enterprise strategy is a complex multi-level entity in which the lower-level strategy supports and complements the higher-level strategy, and the implementation of each ensures the achievement of common goals.

There are four basic strategies of the enterprise:

1. Corporate (portfolio) strategy, which establishes the investment priorities of the organization and plans to allocate resources to the most promising areas of activity; this strategy is aimed at strengthening the competitive position in each type of business, as well as managing the economic portfolio of structural units (strengthening business positions). 
2. Business strategy, which involves the development of approaches to the formation of competitive advantages of the enterprise; aims at combining strategic actions of the main functional units.

3. Functional strategy, which includes a specific list of actions to support the business strategy, helps to achieve the goals of the unit.

4. An operational strategy that addresses issues related to the achievement of the goals of individual units and identifies ways of solving strategically important operational tasks (such as purchasing, inventory management, repair, transportation, advertising, etc.).

The enterprise strategy is described by four elements:

- strategic goals (indicate the direction of activity of the enterprise, establish a method of motivating employees and ways to control the implementation of plans);

- scope of activity (indicates which goods or services and in what markets the enterprise intends to introduce);

- a way to gain competitive advantage (eg high quality, low price, flexibility of delivery, brand, specific characteristics of a product or service, etc.);

- functional strategies (support the implementation of the overall strategy within individual functions and units).

Within a market environment, businesses divide their strategies into three levels:

1) the overall strategy of the enterprise, which involves the selection of a set of goods or services to be presented in selected markets;

2) a competitive strategy for a particular product or market and identifying the appropriate way to compete in that market;

3) a functional strategy (there are usually several such strategies, such as production, marketing, logistics, etc.).

The most popular model of competitive enterprise strategy is M. Porter's concept [15]. He identified four alternative competitive strategies:

- cost leadership that most often requires significant market share, aggressive pricing and investment, cost control, experience, and minimization of research and innovation costs, etc.;
- a differentiation strategy based on the differentiation of the goods or services of the enterprise, as well as on the creation of something different; there are several ways of differentiation: sales methods, basic product characteristics, brand, form, etc.;

- market niche and low pricing strategy and concentrated differentiation strategies are focused on serving the chosen market niche and are able to take advantage of competitors operating within the entire market or within the segment.

The further research considers the varieties of functional strategies in more detail.

Marketing strategy is a strategy of industrial enterprises focused on market values, that is, the development of strategic solutions that allow you to effectively fulfill the objectives of the medium and short-term period of the enterprise. Any marketing strategy depends on the correlation of factors of external and internal environment. The concept of "marketing strategy" means a detailed comprehensive plan of marketing goals of the company.

Effectively developed marketing strategy allows the company to increase the competitiveness of goods and services; expand the client base; increase sales; improve the quality of customer service; develop effective pricing and product policies.

The strategy for the development of research and design works (R\&D) is based on scientific and technical forecasts and is formed taking into account possible inventions and technological breakthroughs in one or another field during the period during which the strategy is being developed. The R\&D strategy is a blueprint for conducting major research on new products, technology, production organization and management, as well as more efficient use of existing products, processes, their development and management.

Production strategy is a functional strategy of creation and development of highly competitive production potential of the enterprise.

The most common manufacturing strategies are:

- strategy for creating new production: acquisition, creation of new production, new use of existing production potential, etc .; 


\section{O. Melnyk, M. Zlotnik}

- strategy of changes in technological process: introduction of new methods of production of products and technologies, use of new materials;

- production organization strategy: production diversification, production rhythm, quality management system, etc.

A financial strategy is the definition of goals for the use of financial resources, methods of financing, and financial planning.

The most commonly used financial strategies are the lending strategy (regulation and control of short-term loans) and the dividend utilization strategy (organization of the dividend payment process).

Personnel management strategy is a strategy aimed at development and improvement of human resources of the enterprise, accumulation of human capital. Most commonly, the following personnel management strategies are used:

- remuneration and motivation strategy, balancing remuneration and profit with overall and support strategies;

- recruitment and training: organization of the training process, organization of analytical centers for selection and development of personnel;

- personnel management strategy: the process of selecting, hiring, training, retraining, employing and stimulating employees to meet the needs of future organizational changes in the enterprise.

Foreign and domestic experience in organizational development shows that the use of strategies makes it much easier to work for longand short-term efficiency and profitability; provides an opportunity to make the organization more manageable, since having a system of strategic plans there is an opportunity to compare the achieved results with the goals set, specified in the form of planned goals.

\section{The evolution of scientific approaches \\ to strategic enterprise management}

In the science of strategic management, there are different directions, which are based on common basic principles, but differently set research priorities, highlighting certain approaches and methodologies. These directions are called scientific schools of strategic management. In the course of acquaintance with the literature, it was found that the most complete analysis of the schools of strategic management is presented in the work of G. Mintzberg, B. Olstrend and J. Lampel [20]. The authors identify 11 major science schools that have a fundamental vision of strategic management. Conditionally they can be divided into three groups:

1. Prescriptive schools.

The first is the design school. The formulation of a strategy, from the point of view of this school, is considered both to design and conscious modeling.

The principal representatives of this school are A. Chandler and K. Andrews [21, 22]. They declared the following requirements for strategy formulation:

- creating strategies should be a rational process of conscious thinking;

- the manager is solely responsible for overseeing the individual's strategic process;

- the model of strategy development should be clearly defined;

- the strategy must be unique and be the result of individual modeling.

The next is a planning school that considers strategy formation as a formal process.

Its founder is the famous management scientist I. Ansoff. This school pays particular attention to the quantitative presentation of the main goals of the enterprise and the development of a sequence of steps and procedures.

The leading role is given to professional "strategic planners", the most important tools are "scenario planning", software like "Project Management" and others.

The third school is a positioning school that treats strategy formation as an analytical process.

The foundations of this school were laid by the military strategists - Sun Tzu [23], K. Clausewitz and others. It also includes the wellknown achievements of the consulting companies Boston Consulting Group and McKinsey. The founders of this school include M. Porter [15].

The basic principles of this school are as follows:

- the strategy reflects the company's position in the market; 
- the process of strategy formation is based on analytical calculations, which result in the selection of one particular position, for example, the position of a leader in a particular segment of the market;

- an important role in the strategic management process is played by third-party analysts and consultants who provide their findings to senior executives.

2. Behavioral schools.

The first behavioral school is the school of strategy formulation.

Representatives of this school include thinkers-economists, who emphasized the role of the entrepreneur's personality and their inherent qualities of intuition, prudence, experience, wisdom, discernment. Among them are K. Marx and J. Schumpeter [24]. According to Schumpeter, an entrepreneur has a greater tendency to take risks in a changing environment because he has a commercial idea.

The strategy strategy school is based on the following principles:

- the strategy is developed intuitively by the entrepreneur leader as a "vision" of the future;

- the process and result of strategy formation is not formalized, as it is based on the experience and beliefs of the manager;

- strategy has the ability to be flexible and responsive to changes in the environment to the extent that these qualities are inherent in the leader.

The next scientific school of strategic management is a cognitive school that understands strategy formation as a mental process. Its founder is L. Simon [25].

Proponents of the cognitive school actively rely on the development of psychologists, and using the typology of individuals determine the individual cognitive style of the manager.

The cognitive process is based on the "mapping" of an existing situation. In this process, maps of both external conditions and maps of causes of behavior, mental models existing in the mind of an experienced leader are created.

The next is a learning school that considers strategy formation as an evolving process.

Previous schools of strategy have one way or the other suggested that one must first work out a strategy, "prepare" it, and then act accordingly. The school of education for the first time refused to accept strategy as something resolved, for a certain period unchanged and took up the problems not of formulation, but of strategy formation, offering the evolutionary path of strategic management.

The principal representative of this school is J. Quinn [26], who suggested that the strategy should be formulated and implemented step by step, with constant consideration of the results of the previous steps. And the results mean not only changes in the external conditions and position of the organization as a whole, but also changes in its individual subsystems. The requirements also include continuous management flexibility, supported by sufficient resources to respond appropriately to change.

Also, the learning school system uses monitoring and benchmarking in strategic management.

The authority school was the first to propose to clarify the formulation of a strategy with the negotiation process.

This school takes into account factors that go beyond the pure economy, it is about its own relationships that relate to a particular organization. In the context of this school, strategy is seen as politics and strategy building as a political process.

Noteworthy are the following theses of the authority school, formulated by L. Bolman and W. Dill [27]:

- organizations are coalitions of different individuals united on a common interest basis;

- the most important decisions concern the allocation of scarce resources, which creates the basis for conflict, which is the central moment of organizational dynamics;

- the goals and decisions of the strategy are the result of position manipulation and stakeholder negotiation.

There are two concepts in the authority school: "micro-authority" (relationships between individuals and groups within an organization) and "macro-authority" (relationships between an organization and the external environment).

M. Porter [15] has done a great deal for the methodology of macro- authority analysis on 


\section{O. Melnyk, M. Zlotnik}

organization. But it must be borne in mind that organizational and inter-organizational effects are increasingly determined not by impersonal market forces (equilibrium vectors) but by regulation and political negotiation.

Within behavioral schools, it is advisable to consider a school of culture that explains strategy formation as a collective process.

In the field of management, the "discovery" of the role of organizational culture belongs to Japanese organizations, as well as to analysts T. Peters and R. Waterman [28].

The basic principles of this school are:

- strategy formulation is a process of social interaction based on beliefs and understanding shared by members of the organization;

- strategy takes the form of perspective and only secondarily positions that are rooted in collective aspirations and is a model that reflects the resources and capabilities of the organization and creates the basis of its competitive advantages;

- culture, and ideology in particular, contribute, rather than strategic change, to the preservation of the current strategy.

The school of environment treats strategy formation as a reactive process.

The school of environment is distinguished by the fact that it puts both the management and the organization itself in dependence on the set of forces of the external environment, which determines the strategy. The most striking representatives of this school are M. Hannan and J. Freeman [29].

The school grew out of a "theory of situational factors" that declared direct dependence: the more stable the external environment, the more careful the planning and formalized structure of organizations. Management is seen as a passive element of the strategic process, its task is to identify external forces and ensure the adaptation of organizations. If the environment poses many different tasks to the organization and offers different opportunities, then the strategies of the organizations become more diverse and multifaceted. schools.

3. Configuration and cooperative strategies

The configuration school views strategy formation as a transformation process. There are two basic concepts in this school: "configuration" (a stable organization structure) and "transformation" (the process of developing and transforming a strategy).

The main provisions of this school include the tenets of different schools, bringing them together, and in a very specific context. The effect of a strategy is determined not by the use of one or another of its attributes, but by their interaction (for example, the combination of a given type of power, a specific environment, a certain type of planning with a specific structure and with a certain leadership style).

The school's theorist was D. Miller [30], who suggested the main theses of the school configuration:

- over a period of time, the organization has a structure that is appropriate to a particular context that determines the behavior and set of strategies of the organization;

- stability periods in a certain sequence are interrupted by transformations - jumps into another configuration, which is the life cycle of the organization;

- the aim of strategic management is to maintain the stability of the organization for a long period and maintain its viability in the event of transformation;

- the process of building a strategy is to choose one or another configuration of elements of strategic management different schools.

The latter is a school of cooperative strategies, which operates with the concepts of "business networks", "collective strategies", "strategic alliances", “joint ventures", etc.

The term "collective strategy" was proposed by G. Astley and C. Fombrun [31] to describe the process of strategy formation. This school also uses the achievements of other schools. This school explores various forms of collaboration: joint ventures, franchising, licensing, and more.

Summarizing the main features of the abovementioned scientific schools of strategic enterprise management, it is advisable to summarize their key characteristics, to analyze the advantages and disadvantages (Table 3 ). 
The comparison of the main scientific schools of strategic enterprise management

\begin{tabular}{|c|c|c|c|}
\hline School & Representatives & Advanteges & Disadvantages \\
\hline \multicolumn{4}{|c|}{ 1. Prescriptive schools } \\
\hline The design school & $\begin{array}{l}\text { A. Chandler, } \\
\text { K. Andrews } \\
{[21,22]}\end{array}$ & $\begin{array}{l}\text { The simplicity and informality } \\
\text { of the process of creating a } \\
\text { strategy }\end{array}$ & $\begin{array}{l}\text { A certain abstractness of thinking } \\
\text { from action, a low level of } \\
\text { flexibility. }\end{array}$ \\
\hline $\begin{array}{l}\text { The planning } \\
\text { school }\end{array}$ & I. Ansoff $[1,2]$ & $\begin{array}{l}\text { A clear sequence of procedures } \\
\text { for developing a strategy. }\end{array}$ & $\begin{array}{l}\text { Fascination with internal procedures } \\
\text { at the expense of the actual choice of } \\
\text { strategy, strategic creativity. }\end{array}$ \\
\hline $\begin{array}{l}\text { The positioning } \\
\text { school }\end{array}$ & $\begin{array}{l}\text { Sun Tzu [23], } \\
\text { K. Clausewitz, } \\
\text { M. Porter [15] }\end{array}$ & $\begin{array}{l}\text { Deepening market analysis, } \\
\text { competitive advantages of the } \\
\text { organization. }\end{array}$ & $\begin{array}{l}\text { The actions of an organization can be } \\
\text { "read" by competitors; the role of the } \\
\text { internal potential of the enterprise is } \\
\text { underestimated. }\end{array}$ \\
\hline \multicolumn{4}{|c|}{ 2. Behavioral schools } \\
\hline $\begin{array}{l}\text { The school of } \\
\text { strategy } \\
\text { formulation }\end{array}$ & $\begin{array}{l}\text { K. Marx, } \\
\text { J. Schumpeter } \\
{[24]}\end{array}$ & $\begin{array}{l}\text { Best suited for small businesses } \\
\text { and niche markets. }\end{array}$ & $\begin{array}{l}\text { Significant dependence of strategic } \\
\text { management on the intuition and } \\
\text { charisma of the leader. }\end{array}$ \\
\hline $\begin{array}{l}\text { The cognitive } \\
\text { school }\end{array}$ & $\begin{array}{l}\text { L. Simon, } \\
\text { G. Davies [25] }\end{array}$ & $\begin{array}{l}\text { Analyze cause and effect } \\
\text { relationships when mapping a } \\
\text { situation. }\end{array}$ & $\begin{array}{l}\text { Difficulties in changing strategy; } \\
\text { complexity of the psychology of } \\
\text { knowledge in the mind of the } \\
\text { manager-strategist. }\end{array}$ \\
\hline The learning school & J. Quinn [26] & $\begin{array}{l}\text { Continuous process of improving } \\
\text { the strategy. }\end{array}$ & $\begin{array}{l}\text { Learning can become an end in } \\
\text { itself, which causes the eternal } \\
\text { "incompleteness" of the process of } \\
\text { strategy formation. }\end{array}$ \\
\hline $\begin{array}{l}\text { The authority } \\
\text { school }\end{array}$ & $\begin{array}{l}\text { L. Bolman, } \\
\text { W. Dill [27], } \\
\text { M. Porter [15] }\end{array}$ & $\begin{array}{l}\text { Growth through conflict of } \\
\text { interest. }\end{array}$ & $\begin{array}{l}\text { The risk of decline from the effects } \\
\text { of conflict and instability. }\end{array}$ \\
\hline $\begin{array}{l}\text { The school of } \\
\text { culture }\end{array}$ & $\begin{array}{l}\text { T. Peters, } \\
\text { R. Waterman } \\
{[28]}\end{array}$ & $\begin{array}{l}\text { Involvement of all employees } \\
\text { in the awareness of the } \\
\text { organization's strategy }\end{array}$ & $\begin{array}{l}\text { The culture of the organization is } \\
\text { usually perceived by the employee as } \\
\text { simplistic and partly erroneous. }\end{array}$ \\
\hline $\begin{array}{l}\text { The school of } \\
\text { environment }\end{array}$ & $\begin{array}{l}\text { M. Hannan, } \\
\text { J. Freeman [29] }\end{array}$ & $\begin{array}{l}\text { Reorientation from } \\
\text { factors to the } \\
\text { environment. }\end{array}$ & $\begin{array}{l}\text { Alternative to "choice" since there is } \\
\text { only one strategy in each specific } \\
\text { environment. }\end{array}$ \\
\hline \multicolumn{4}{|c|}{ 3. Configuration and cooperative strategies schools } \\
\hline $\begin{array}{l}\text { The configuration } \\
\text { school }\end{array}$ & $\begin{array}{l}\text { P. Handawall, } \\
\text { D. Miller [30] }\end{array}$ & $\begin{array}{l}\text { The synthesis of previous } \\
\text { schools. knowledge }\end{array}$ & $\begin{array}{l}\text { By focusing on the "jumps", other } \\
\text { important moments of "inter- } \\
\text { transformation" may be missed. }\end{array}$ \\
\hline $\begin{array}{l}\text { The school of } \\
\text { cooperative } \\
\text { strategies }\end{array}$ & $\begin{array}{l}\text { G. Astley, } \\
\text { C. Fombrun } \\
{[31]}\end{array}$ & $\begin{array}{l}\text { Focusing the strategy on achieving } \\
\text { benefits not only for the orga- } \\
\text { nization but also for its partners. }\end{array}$ & $\begin{array}{l}\text { The focus may be dispersed on } \\
\text { various forms of collaboration and } \\
\text { the company may lose its identity. }\end{array}$ \\
\hline
\end{tabular}

The scientific schools of strategic enterprise management have considered the process of strategy formation in various aspects and initiated the development of modern strategic management.

\section{Basic models of strategic enterprise management}

The main goal of implementing strategic management is the need to ensure the continuous and sustainable development of the company in the dynamic environment. The company's transition to strategic management will provide it with the opportunity to anticipate future development and make timely management decisions, goals and strategies.

The strategic management of the enterprise is carried out in a certain sequence. The first stage defines the mission of the enterprise - the main 


\section{O. Melnyk, M. Zlotnik}

reason for its existence. Then a vision is developed - a future picture of the operation of the enterprise in the long run. In the following stages, the main goals that the company strives to achieve and the values that the main principles that it will stick to in the process of functioning are determined. After that, the analysis of the external environment and the analysis of the potential (internal environment) of the enterprise is conducted. Based on the results of the analysis, a general (corporate) strategy is formed, which is then detailed into lower levels of enterprise management in the form of functional and resource strategies. When the enterprise strategy is developed, the stage of its implementation comes. According to the results and in the process of implementation of the strategy constant monitoring and evaluation of the obtained results is carried out. If deviations from the general (corporate) strategy occurred in the course of strategy implementation, then the strategy is adjusted by making strategic changes.

Based on the essence of strategic management, the main stages and the sequence of formation of strategic behavior can be distinguished. Subsequently, the substantive side of each of the selected stages is considered.

When it comes to choosing a strategic management model, there are some difficulties. In the development of strategy theory, different researchers have proposed different approaches.

Each strategic management model is based on a basic structure that includes an analysis of the environment, defining the mission and goals, selecting and implementing the strategy, as well as evaluating and monitoring implementation (Fig. 1).

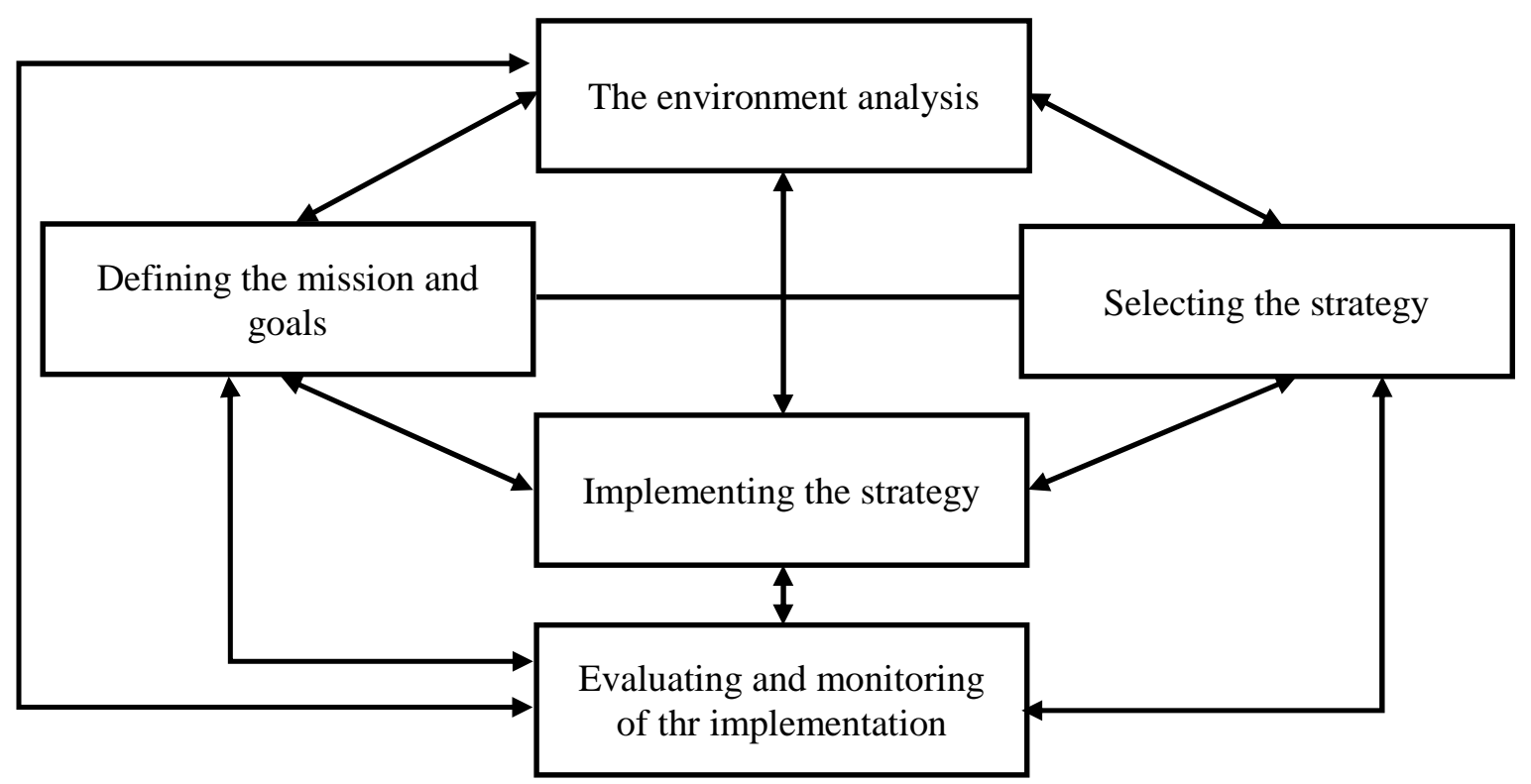

Fig. 1. The structure of strategic enterprise management

In order to deepen the analysis of basic models of strategic management, it is advisable to consider models developed by Ukrainian and foreign scientists.

I. Ansoff as the basis of the strategic management model is based on decisions that are appropriate to make when formulating a strategy: assessment of the potential of the organization; assessment of external opportunities and threats; formulation of goals and choice of tasks; decision on diversification and choice of diversification strategy; choice of competitive strategy; formation of components of diversification strategy and competitive strategy in the form of separate projects.

Domestic author Z. Shershneva [8] made a significant contribution to the construction of a sound sequence of actions in the formation of a strategic management system. The conceptual scheme of strategic enterprise management they offer differs from the previously proposed models by the extended, correct and clear description of the following stages:

1) concept; 
2) diagnostics (strengths and weaknesses of the enterprise);

3) the formation of the goals of the enterprise;

4) choice of strategy;

5) development of the system of plans, projects and programs of enterprise development;

6) strategic control.

A. Thompson and A. Strickland [7] believe that the strategic management model should begin with a strategic analysis of the value of the enterprise. This process includes internal audit, business analysis, external audit and, as a result, goal setting. In order to achieve the set goals, a strategic choice of alternative paths is made. In assessing and selecting alternatives, factors such as organizational structure, functions, people and systems are taken into account. The final stage of the model is monitoring and evaluation. The authors extended the well-known model of $\mathrm{M}$. Porter's five forces and proposed a model of seven forces that influence strategic management (Fig. 2).

F. David [32] believes that strategic enterprise management begins with the establishment and development of the mission, followed by internal and external audits to formulate a strategy, establish long-term goals, define policies and allocate resources. An important role in this model is given to the feedback, measurement of the effectiveness of the strategy and its evaluation (Fig. 3).

O. Vikhansky proposes to consider the strategic management model as a dynamic set of five interdependent management processes: environmental analysis; defining the mission and goals; choice of strategy; strategy implementation; performance evaluation and control [5].

S. Popov proposed a relatively simple model, which to some extent synthesizes the previously proposed models. The main components of strategic management, according to the scientist, are: analysis of the external environment of the organization; internal diagnostics (evaluation of strengths and weaknesses) of the organization; defining the mission and goals of the organization; development, evaluation and selection of alternative strategies for specific subsystems of the organization; development and detailed definition of corporate strategy as a program of concrete actions; implementation of the strategy; results evaluation and feedback [14].
R. Lynch believes that the strategic management model should include two approaches prescriptive (universal) and emergent (situational). The prescriptive approach is based on the stages of strategic analysis, development and implementation of the strategy. At these stages, there is an analysis of the environment, the development of vision, goals and mission of the organization, the analysis of resources, the development of benefits. At the stage of strategy implementation, rational choice of priorities is made, finding the right way to achieve the set goals and approval of the appropriate structure and mechanism of management. An emergent situational approach involves analyzing a turbulent external environment, identifying the vision, mission and goals of the organization, analyzing resources and developing and implementing a strategy. It is worth noting that the prescriptive approach is characterized by long-term monitoring, and the emergent - by constant one [33]. According to the author, the combination of the two approaches is the most effective for successful strategic management of the enterprise (Fig. 4).

Famous American scientist I. Ansoff has developed 4 models of strategic management $[1,2]$ :

1. Strategic management through the choice of strategic positions - involves the analysis of prospects of the enterprise; identifying priorities and allocating resources among various promising activities of the enterprise; analysis of possible diversification of the enterprise; forecast of dynamics of instability factors; planning new strategies that meet expected levels of environmental instability; anticipation of organizational changes and capabilities of the enterprise.

2. Management based on the ranking of strategic tasks - occurs in the enterprise management system by categorizing tasks according to the degree of urgency and importance; the highest priority tasks are transferred to the relevant units of the enterprise for preparation and decision making; to control the decision-making process to ensure that the strategic implications of the decisions are consistent with the management system; continuous renewal and review of current strategic objectives.

3. Strategic emergency management is used when new problems are not only poorly anticipated and develop very quickly, but also occur almost suddenly without the expected prognosis. 


\section{O. Melnyk, M. Zlotnik}

Weak signal control (anticipative) model is based on the assumption that any adverse event or prospect of opportunity growth does not occur suddenly, but is conditioned by the appearance of predictor signals or "weak signals".

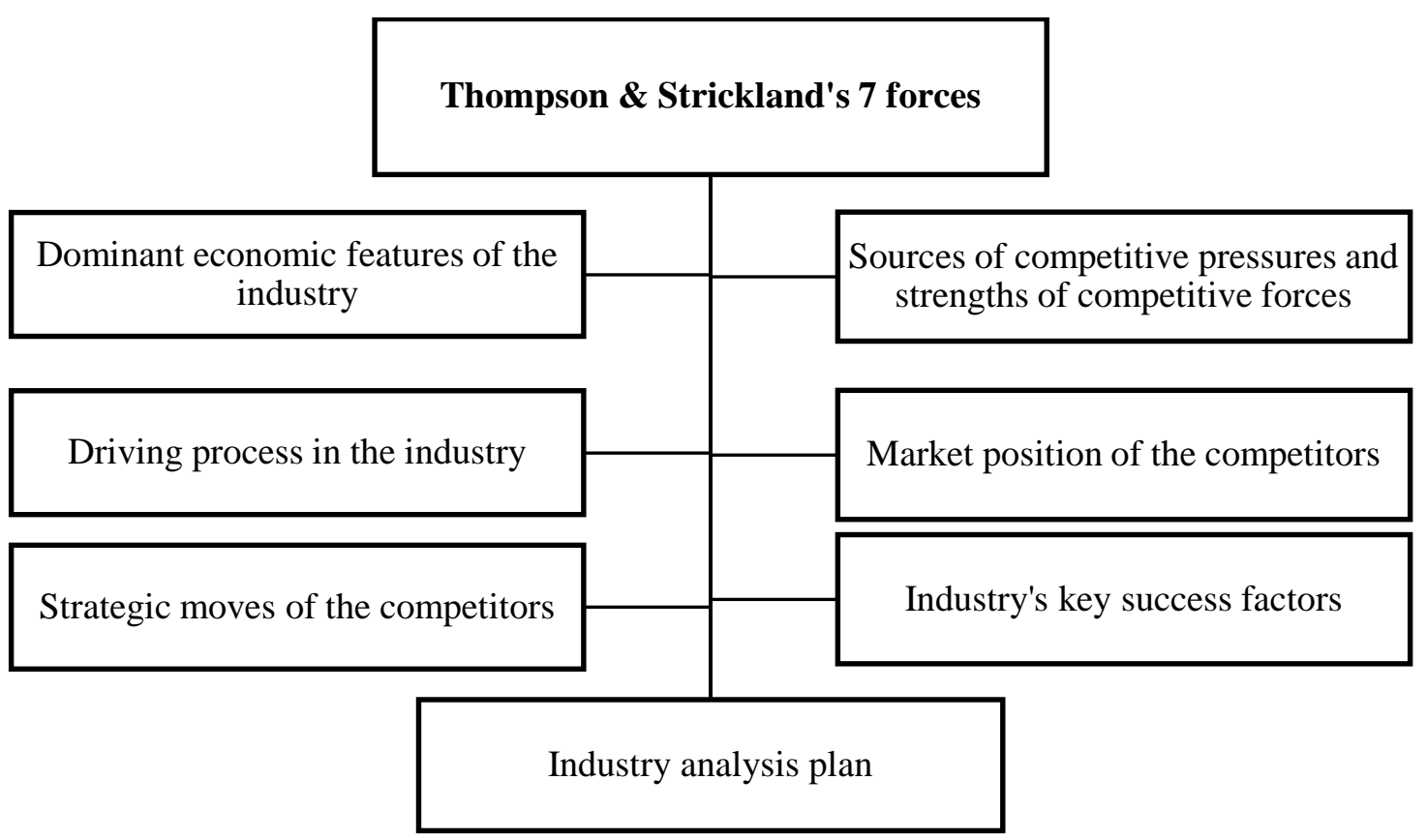

Fig. 2. Model of the seven forces of A. Thompson and A. Strickland [7]

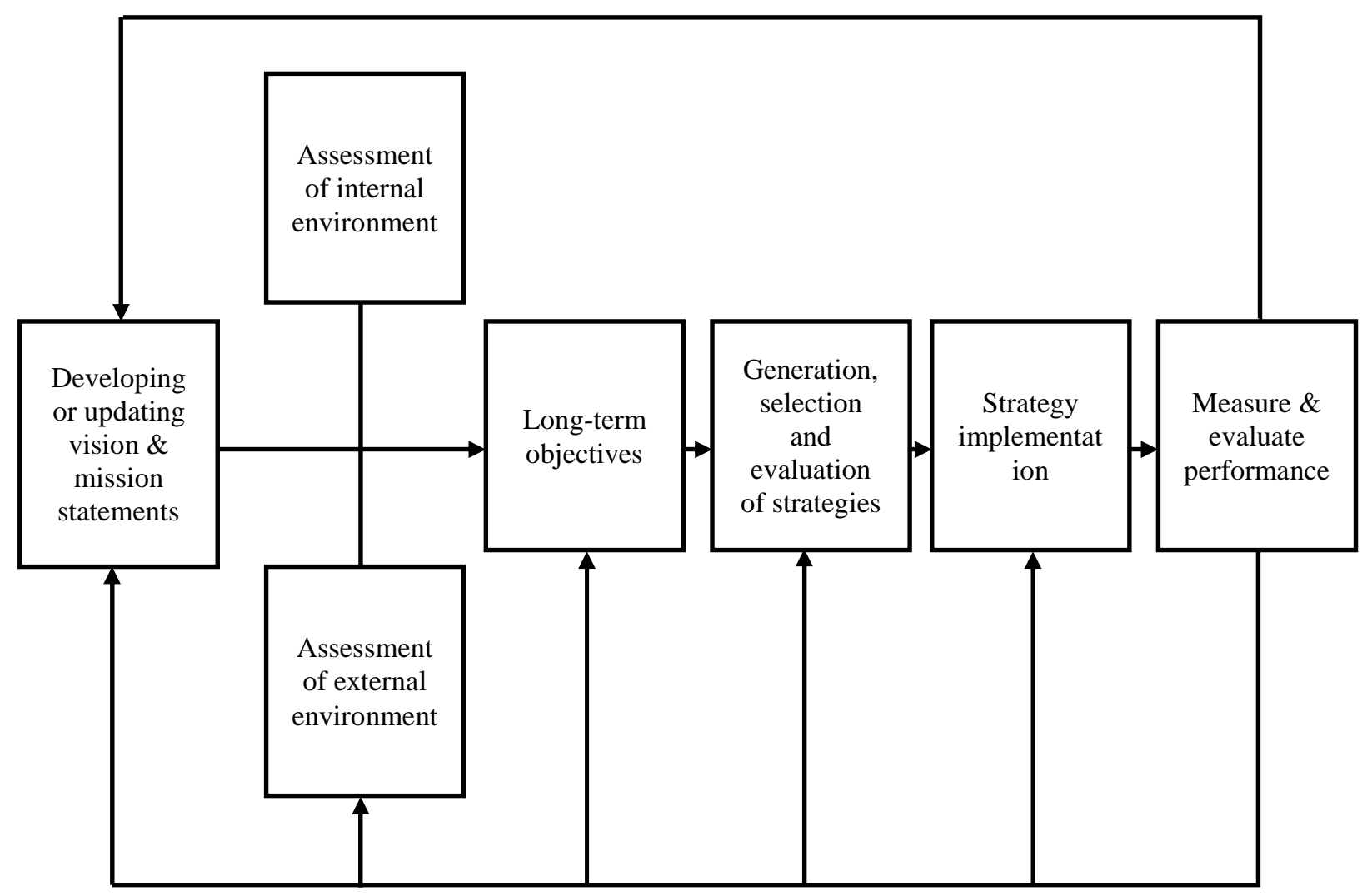

Fig. 3. F. David's strategy management model [32] 


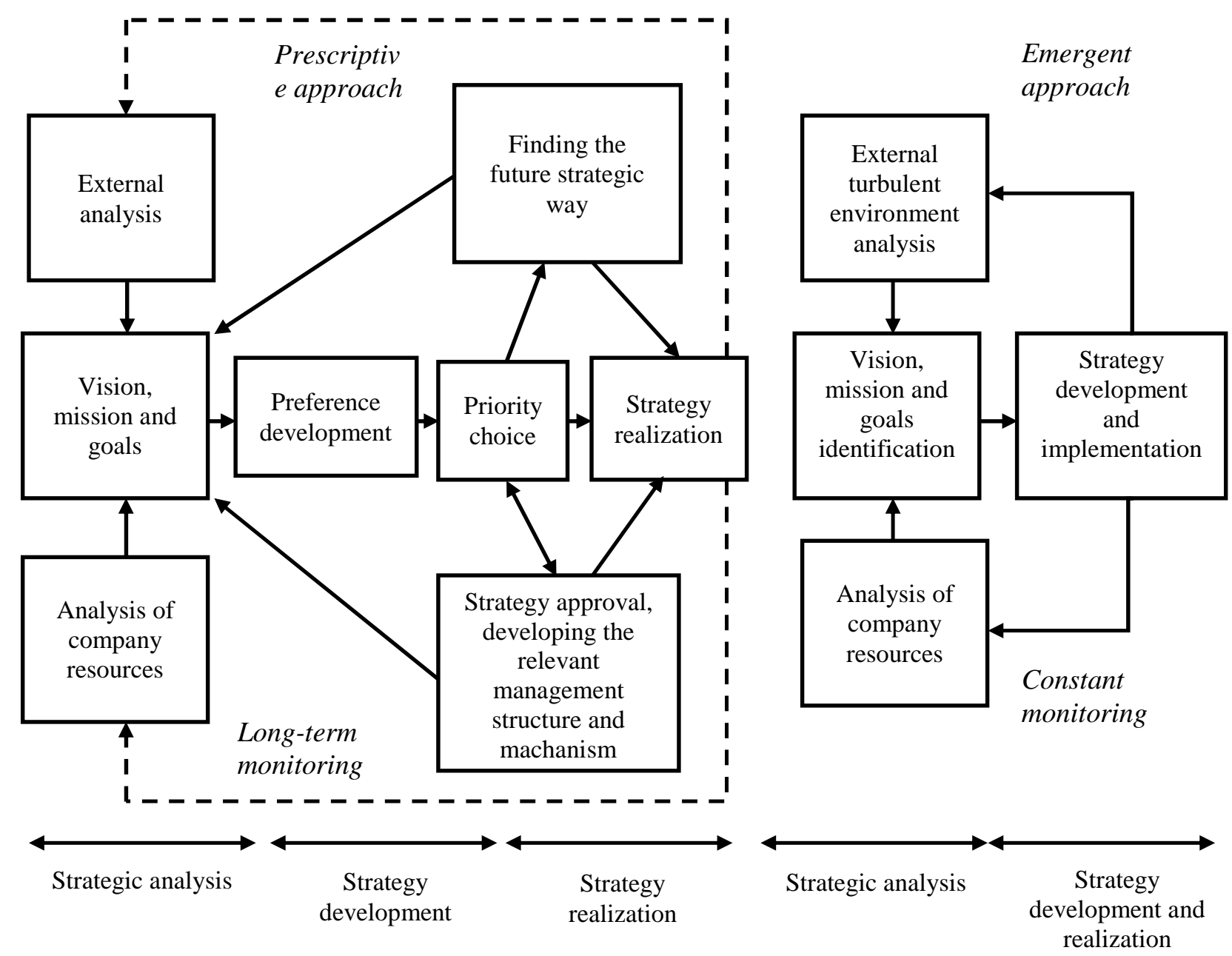

Fig. 4. R. Lynch's strategy management model [33]

Ukrainian authors propose the following models of strategic management [34]:

1. Entrepreneurial - characterized by the foresight of a leader who is actively looking for new opportunities, goes to various changes and making informed decisions. This type of management is most common in enterprises that are newly established or are in financial difficulty and have strong managers.

2. Adaptive - based on the implementation of prudent measures to respond to problems and identify opportunities for their gradual solution. This type of management is used by managers of enterprises with sustainable economy. It is effective under stable external conditions. Lower level executives have some freedom to execute a strategy.

3. Planning-based model - provides for systematic benchmarking, strategy development and decision justification. This type of management is typical of large enterprises with sufficient resources to carry out detailed comparative analysis. Planners are involved in developing this strategy.

4. Based on the "strategic gap" - implies the formation of a "field of strategic decisions" that must be taken by the managers of the enterprise in order to transform the existing trends in the proper direction in order to achieve the required parameters of the enterprise development. This approach focuses on aligning "what is possible" with "what needs to be achieved".

5. Based on the strategic advantages of the company - based on the use of the results of SWOT analysis.

6. Based on creating and maintaining an enterprise's competitiveness - involves focusing the enterprise on long-term competitiveness through the use of a wider range of strategic measures. The key factors of success of the enterprise are determined. 


\section{O. Melnyk, M. Zlotnik}

7. Aimed to create a positive image of the company - involves the development of an investment option for long-term development of the enterprise, as enterprises with a reliable reputation have loyal customers, reliable partners, wide access to credit, investments.

8. Based on the size of the enterprise involves the formation and effective use of a specific organizational system, which assumes the existence (appointment) of responsible persons (units), who perform separate work on the development and implementation of various strategic plans.

Each of these models has both advantages and disadvantages, which are analyzed in Table 4.

Table 4

\section{Advantages and disadvantages of different strategic management models}

\begin{tabular}{|c|c|c|c|}
\hline No. & $\begin{array}{l}\text { The name of the strategic } \\
\text { management model }\end{array}$ & Advantages & Disadvantages \\
\hline 1 & 2 & 3 & 4 \\
\hline 1 & $\begin{array}{l}\text { Strategic management through } \\
\text { the choice of strategic positions }\end{array}$ & $\begin{array}{l}\text { The ability to analyze prospects, } \\
\text { identify priorities and allocate } \\
\text { enterprise resources }\end{array}$ & $\begin{array}{l}\text { The position chosen may not be } \\
\text { in line with market trends }\end{array}$ \\
\hline 2 & $\begin{array}{l}\text { Management based on the } \\
\text { ranking of strategic tasks }\end{array}$ & $\begin{array}{l}\text { Reviewing current strategic objectives } \\
\text { through categorization, analysis and } \\
\text { continuous renewal }\end{array}$ & $\begin{array}{l}\text { Not taking into account the } \\
\text { external environmental impact of } \\
\text { the enterprise }\end{array}$ \\
\hline 3 & $\begin{array}{l}\text { Strategic emergency mana- } \\
\text { gement }\end{array}$ & $\begin{array}{l}\text { Enables quick response and mana- } \\
\text { gement decisions at the enterprise }\end{array}$ & $\begin{array}{l}\text { The expectation of a strategic } \\
\text { surprise can divert the attention } \\
\text { of an enterprise from solving } \\
\text { operational tasks }\end{array}$ \\
\hline 4 & $\begin{array}{l}\text { Weak signal control (antici- } \\
\text { pative) management }\end{array}$ & $\begin{array}{l}\text { The enterprise's response to strategic } \\
\text { announcements of strategic surprises }\end{array}$ & $\begin{array}{l}\text { Anticipation of the signal-herald } \\
\text { may divert the attention of the } \\
\text { enterprise from solving } \\
\text { operational problems }\end{array}$ \\
\hline 5 & Entrepreneurial & $\begin{array}{l}\text { Orientation to the key role of a leading } \\
\text { manager-entrepreneur }\end{array}$ & $\begin{array}{l}\text { Inability to make managerial } \\
\text { decisions collectively }\end{array}$ \\
\hline 6 & Adaptive & $\begin{array}{l}\text { Cautious enterprise response to problems } \\
\text { and their gradual solution }\end{array}$ & $\begin{array}{l}\text { Difficult to apply in dynamic } \\
\text { environmental conditions }\end{array}$ \\
\hline 7 & Planning-based model & The use of strategic planning & $\begin{array}{l}\text { Based only on the possibility of } \\
\text { predicting the future }\end{array}$ \\
\hline 8 & Based on the "strategic gap" & $\begin{array}{lll}\text { Collective } & \text { strategic } & \text { management } \\
\text { decisions } & & \\
\end{array}$ & $\begin{array}{l}\text { Difficulties on finding a strategic } \\
\text { niche }\end{array}$ \\
\hline 9 & $\begin{array}{l}\text { Based on the strategic advanta- } \\
\text { ges of the company }\end{array}$ & $\begin{array}{l}\text { Identification and developing the } \\
\text { strengths of the enterprise }\end{array}$ & $\begin{array}{l}\text { Rejecting the destabilizing } \\
\text { influence of the weaknesses of } \\
\text { the enterprise }\end{array}$ \\
\hline 10 & $\begin{array}{l}\text { Based on creating and } \\
\text { maintaining an enterprise's } \\
\text { competitiveness }\end{array}$ & $\begin{array}{l}\text { The assessment and development of } \\
\text { enterprise competitiveness }\end{array}$ & $\begin{array}{l}\text { Focus on continuous, stable long- } \\
\text { term competitiveness of the } \\
\text { enterprise }\end{array}$ \\
\hline 11 & $\begin{array}{l}\text { Aimed to create a positive } \\
\text { image of the company }\end{array}$ & $\begin{array}{l}\text { Formation of a positive image of the } \\
\text { enterprise in the market }\end{array}$ & $\begin{array}{l}\text { Focus on continuous, stable long- } \\
\text { term development of the } \\
\text { enterprise }\end{array}$ \\
\hline 12 & $\begin{array}{l}\text { Based on the size of the } \\
\text { enterprise }\end{array}$ & $\begin{array}{l}\text { Building a specific organizational } \\
\text { structure of the enterprise }\end{array}$ & $\begin{array}{l}\text { Not taking into account the } \\
\text { external environmental impact of } \\
\text { the enterprise }\end{array}$ \\
\hline
\end{tabular}

Summarizing the authors' approaches to the implementation of strategic management, it can be argued that the specific nature of enterprises and the dynamic nature of the environment make it 
impossible to develop a universal model of strategic management.

However, there are common features that are characteristic of all the models analyzed:

- formulation of the mission;

- setting goals;

- analysis of the internal and external environment;

- developing and analyzing strategic alternatives and choosing the best strategy;

- formation of long-term strategic plans, projects and programs;

- implementation of plans, projects and programs;

- control over implementation;

- evaluation of the results of the strategy implementation and its adjustment.

\section{Conclusions}

The main idea that permeates all the analyzed basic models of strategic management is to take into account the interconnection and interaction of the external and internal environment of the organization in defining the mission and goals. Strategies play the role of tools to accomplish the stated mission and achieve the stated goals, and for the successful implementation of the strategies, all functional units of the enterprise need to work smoothly in the strategic mode.

Strategic management is largely based on human potential as the basis of the organization, ensuring compliance of production activities with market demands. In today's market environment, strategic management must be characterized by a high degree of flexibility in order to implement timely changes in the organization in response to changes in the environment. Strategic benchmarks for improving the enterprise and its individual subsystems must be the basis for ensuring its longterm competitive existence.

The definitions of "enterprise strategic management" and "enterprise strategy" were analyzed during the study and the main strategies used in a market environment were examined. An enterprise strategy is seen as a systematic plan for its potential behavior in the context of incomplete information on the future development of the environment and entrepre- neurship, including the formation of a mission, long-term goals, as well as decision-making paths and rules for the most effective use of strategic resources, strengths and opportunities, elimination of weaknesses and protection against environmental threats for future profitability. The application of strategic management and strategies at enterprises makes it possible to use economic, organizational and technical capabilities of production, to coordinate work on enterprise development in a timely manner.

With regard to further research, the development of a new dynamic approach to strategic management is relevant today. The existing concept of strategic planning needs to be complemented by processes of creating and maintaining competitive advantage, as competition in the global market is exacerbated at a critical pace.

In addition to formulating a strategy, it is equally important to ensure its effective implementation. To this end, three basic elements must be agreed upon in an organization: the organization's strategy, employees, and the management system. Each of the above elements is a necessary condition that determines the effectiveness of the implementation of the adopted strategy. Together, they form a kind of base that allows to create an effective management process.

In a new market environment for long-term competitive advantage, companies must take into account new concepts and methods that are based on balancing the unique value of the company, its core competencies, social responsibility to owners and creditors, employees and the local community, before customers, in front of the natural environment. Equally important is taking into account global trends such as increasing tolerance for different groups of people, focusing on a more environmentally friendly lifestyle and conscious consumption, and more.

Given the uncertainty of the environment, the variety of methods developed and the lack of information barriers, companies have the opportunity to develop by experimenting with different models of strategic management and rationally using their own resources and competencies. 


\section{References}

1. Ansoff, I., Kipley, D., Lewis, A., Helm-Stevens, R., \& Ansoff, R. (2018). Implanting strategic management. Springer.

2. Ansoff, I. (1989). Strategicynyi menedgment, Economika, Moskva, Russia [In Russian].

3. Romaniuk, L. (2009). Suchasni tendentsii stratehichnoho upravlinnia pidpryiemstvom. Naukovi pratsi KNTU. Ekonomichni nauky, vol. 15 [In Ukrainian].

4. Martinenko, M. and Ignatieva I. A. (2006). Strategicheskiy manegement, Karavella, Kiev, Ukraine [In Russian].

5. Vikhanskiy, O. (2013). Strategicheskoe upravlenie. Moskva: Gardariki. 296 p. [In Russian].

6. Kadyrov, M. (2000). Sistema strategicheskogo upravlenija kak osnova restrukturizacii biznesa. Vestnik TISBI, 2, pp. 12-14 [In Russian].

7. Thompson, A., Strickland, A., \& Gamble, J. (2015). Crafting and executing strategy: Concepts and readings. McGraw-Hill Education.

8. Shershnova, Z. (2004). Strategicheskoe ypravlinnya [Strategic management], KNEU, Kiev, Ukraine, 699 p. [In Russian].

9. Hatten, K. (1975). Strategy, Beer and Profits. Working paper 75-14, Harvard Business School.

10. Higgins, J., Vincze, J. (1993). Strategic Management. Text and Cases. Fifth Edition, Harcourt Brace Jovanovich College Publishers.

11. Schendel, D., Patton, G. (1978). A Simultaneous Equation Model of Corporate Strategy. Management Science, p. 1611-1621.

12. Smith, G., Arnold, D., Bizzell, B. (1991). Business strategy and policy. Houghton Mifflin Co, 380 p.

13. Kleiner, G. (1997). Predpriyatiya v nestabil'noj ekonomicheskoj srede: riski, strategii, bezopasnost'. Moskva, Ekonomika [In Russian].

14. Popov, S. (2019). Strategicheskij menedzhment: aktual'nyj kurs. Moskva, Izdatel'stvo YUrajt, 463 p. [In Russian].

15. Porter, M. (1980). Industry structure and competitive strategy: Keys to profitability. Financial analysts journal, 36(4), 30-41.

16. Kindratska, H. I. (2010). Stratehichnyi menedzhment. Lviv: Lviv Polytechnic National University. 408 p. [In Ukrainian].

17. Veles'ko, E., Bykov, A., Drazhek, Z. (1997). Strategicheskoe upravlenie: Praktika prinyatiya sistemnyh reshenij. Mn.: Tekhnalogiya; Izd-vo BGEU, 199 p. [In Russian].
18. Oster, M. (1979). Celevoe upravlenie organizaciej, Moskva, Sov. Radio. [In Russian].

19. Henderson, B. (1989). The origin of strategy. Harvard business review. Nov.- Dec. pp. 139-143.

20. Mintsberg, G., Alsterend, B., Lempel, D. (2002). Skoly strategiy. Strategicheskoe safary: ekskyrciya po debryam strategiy menegmenta. Piter, SanktPeterburg, Russia [In Russian].

21. Andrews, K. (1971). The Concept of Corporate Strategy, Dow Jones. Irwin, Homewood, 1971, 245 p.

22. Chandler, A. (1962). Strategy and Structure; Chapters in the History of the Industrials Enterprises. Cambridge, Mass: MIT Press, 490 p.

23. Giles (2013). Sun Tzu On The Art Of War. Abingdon, Oxon: Routledge.

24. Schumpeter, J., Backhaus, U. (2003). The Theory of Economic Development. The European Heritage in Economics and the Social Sciences, vol 1. Springer, Boston, MA.

25. Simon, L, Davies, G. (1996). A contextual approach to management learning. Organization studies, pp. 269-289.

26. Quinn, J. (1992). Intelligent Enterprise. Free Press, New York.

27. Dill, W. (1958). Environment as an influence on managerial autonomy. Administrative Science Quarterly, pp. 409-443.

28. Peters, Thomas J. (1982). In search of excellence: lessons from America's best-run companies. New York :Harper \& Row.

29. Hannan, Michael and Freeman, J. (1977). The Population Ecology of Organizations. American Journal of Sociology, Vol. 82, Issue 5.

30. Miller, K. D. (1992). A framework for integrated risk management in international business. Journal of international business studies, 23(2), pp. 311331.

31. Astley, W., Fombrun, C. (1983). Collective Strategy: Social Ecology of Organizational Environments. Academy of Management Review, Vol. 8, No. 4.

32. David, F. (2016). Strategic management: A competitive advantage approach, concepts and cases. Pearson-Prentice Hall.

33. Lynch, R. (1997). Corporate Strategy. Aldersgate Consultancy Limited.

34. Rulev, V., Gutkevich S. (2011). Strategicheskiy manegement. Kiev, TSUL, 312 p. [In Russian]. 